\section{Blastomycotic Multifocal Arthritis and Osteomyelitis in the Urban Setting}

\section{To the Editor:}

Arthritis due to blastomycosis is uncommon and reports of multiple joint involvement are rare. Blastomycosis dermatitidis is endemic in Midwest states around the Great Lakes, the southeast, and the south central United States ${ }^{1,2}$. Humans acquire this fungus by inhalation of spores from the soil, usually in rural settings ${ }^{3}$. Infection by blastomycosis is most frequently found in adults aged 20-50 years ${ }^{4,5}$, with annual incidence reported in up to 100 cases per 100,000 people in specific areas of the United States ${ }^{6}$. In children, cases are infrequent, accounting for 3\%-10\% of total reported cases, with pneumonia being the most common manifestation ${ }^{7}$. Less commonly, blastomycosis has been reported to cause arthritis and/or osteomyelitis in children ${ }^{8,9}$. Blastomycotic arthritis is usually reported as an acute monoarticular arthritis that may be asymptomatic. Juxtaarticular involvement may lead to osteomyelitis. Involvement of multiple joints is very atypical. In children, only 3 reports have documented arthritis as a presenting manifestation of blastomycosis $8,9,10$. Of these, only 1 report discusses a child presenting with arthritis of more than 1 joint ${ }^{10}$.

We describe 7 cases of blastomycotic musculoskeletal involvement including osteomyelitis and arthritis with and without accompanying arthritis in children. Two children had more than 1 affected joint, and the majority of these cases were diagnosed in patients without rural exposure, suggesting a possible migration of blastomycosis into urban areas.

The medical records of 31 children diagnosed with culture-proven

Table 1. Patient demographics, clinical findings, radiographic and laboratory data, treatment, and clinical sequelae for 7 patients, all male. All cases led to full recovery. Normal values based on laboratory standards at Children's Hospital of Wisconsin: leukocyte count 4.0 to $10.5 \times 10^{3} / \mu 1$; C-reactive protein $(\mathrm{CRP})$ 1 to $1.0 \mathrm{mg} / \mathrm{dl}$; erythrocyte sedimentation rate (ESR) $1-10 \mathrm{~mm} / \mathrm{h}$; CNS: central nervous system; MRI: magnetic resonance imaging.

\begin{tabular}{|c|c|c|c|c|c|c|c|c|c|}
\hline $\mathrm{Pt}$ & $\begin{array}{l}\text { Age, yrs, } \\
\text { race }\end{array}$ & $\begin{array}{c}\text { Chief wit } \\
\text { Complaint }\end{array}$ & $\begin{array}{l}\text { Organ Systems } \\
\text { vith Physical Findings } \\
\text { on Admission }\end{array}$ & $\begin{array}{l}\text { Radiographic } \\
\text { Findings }\end{array}$ & $\begin{array}{l}\text { Leukocyte } \\
\text { Count, } \mu 1\end{array}$ & $\begin{array}{l}\text { Pathology Site } \\
\text { Confirming } \\
\text { Blastomycosis }\end{array}$ & $\begin{array}{l}\text { Culture Site } \\
\text { Confirming } \\
\text { Blastomycosis }\end{array}$ & $\begin{array}{c}\text { Initial } \\
\mathrm{ESR}, \mathrm{mm} / \mathrm{h}\end{array}$ & $\begin{array}{l}\text { Initial } \\
\mathrm{CRP} \text {, } \\
\mathrm{mg} / \mathrm{dl}\end{array}$ \\
\hline 1 & $\begin{array}{l}\text { 13, } \\
\text { Hispanic } \\
\text { s }\end{array}$ & $\begin{array}{l}\text { Weight loss, } \\
\text { fever, cough, } \\
\text { hemoptysis, } \\
\text { joint pain and } \\
\text { swelling, scalp } \\
\text { soft tissue swelling }\end{array}$ & $\begin{array}{l}\text { Skin, lungs } \\
\text { joints, bone }\end{array}$ & $\begin{array}{l}\text { Bone scan-abnormal uptake in } \\
\text { left distal clavicle, proximal right } \\
\text { humerus, distal right radius, } \\
\text { distal diaphysis of left tibia }\end{array}$ & 15,400 & Bone & Skin & $>100$ & 4.5 \\
\hline 2 & $\begin{array}{c}15, \\
\text { African } \\
\text { American }\end{array}$ & $\begin{array}{l}\text { Cough, fever, } \\
\text { joint pain and } \\
\text { swelling, } \\
\text { pustule on nose }\end{array}$ & $\begin{array}{l}\text { Skin, lung, } \\
\text { joint, bone, } \\
\text { CNS }\end{array}$ & $\begin{array}{l}\text { MRI left elbow-joint effusion, soft } \\
\text { tissue edema, abnormal bone signal } \\
\text { in humerus and radius suggestive } \\
\text { of osteomyelitis } \\
\text { MRI left hip-effusion in left hip } \\
\text { joint space } \\
\text { Bone scan-abnormal uptake of bilateral } \\
\text { elbows, mandible, and distal right fibula }\end{array}$ & 12,600 & Not available & Bone & 86 & 8.6 \\
\hline 3 & $\begin{array}{c}12, \\
\text { White }\end{array}$ & Joint pain & Joint, bone & $\begin{array}{l}\text { MRI right elbow-aggressive appearing } \\
\text { lesion in distal humerus with peripheral } \\
\text { enhancement extending into joint space; } \\
\text { diffuse joint effusion }\end{array}$ & 6,400 & Bone & Bone & 57 & 3.7 \\
\hline 4 & $\begin{array}{c}\text { 7, } \\
\text { Hispanic }\end{array}$ & Joint pain & Bone & $\begin{array}{l}\text { MRI left knee-focus of osteomyelitis in } \\
\text { distal left femoral metaphysis with focal } \\
\text { bony abscess formation, no joint effusion } \\
\text { Bone scan-abnormal uptake of distal femoral } \\
\text { metaphysis }\end{array}$ & 8,700 & Bone & Bone & 23 & 0.3 \\
\hline 5 & $\begin{array}{c}6, \\
\text { Hispanic }\end{array}$ & Skin lesion & Skin, joint, bone & $\begin{array}{l}\text { MRI left femur-abnormal bone signal in left } \\
\text { lateral distal femoral epiphysis suggestive of } \\
\text { osteomyelitis, including joint effusion of } \\
\text { left knee } \\
\text { Bone scan-abnormal uptake in left lateral } \\
\text { distal femoral epiphysis }\end{array}$ & 4,400 & Skin & Not available & $\begin{array}{c}\text { Not } \\
\text { available }\end{array}$ & $<0.3$ \\
\hline 6 & $\begin{array}{c}17 \\
\text { African } \\
\text { American }\end{array}$ & $\begin{array}{l}\text { Weight loss, } \\
\text { night sweats, } \\
\text { joint pain and } \\
\text { swelling, blister } \\
\text { on lip }\end{array}$ & Skin, joint, bone & $\begin{array}{l}\text { MRI left lower extremity-bone marrow edema } \\
\text { in talar dome, hairline fracture of lateral } \\
\text { distal tibia with overlying joint effusion } \\
\text { Bone scan-abnormal uptake of left shoulder, } \\
\text { left knee, bilateral ankles, right mid distal } \\
\text { foot, left glenohumeral joint, right tenth rib, } \\
\text { left eighth rib, left costovertebral junction, } \\
\text { left distal femoral epiphysis, left femoral condy }\end{array}$ & a 10,900 & Bone & Bone & $\begin{array}{c}\text { Not } \\
\text { available }\end{array}$ & 15.4 \\
\hline 7 & $\begin{array}{c}16, \\
\text { African } \\
\text { American }\end{array}$ & $\begin{array}{l}\text { Weight loss, } \\
\text { joint pain and } \\
\text { swelling, } \\
\text { swelling on nose } \\
\text { and chest }\end{array}$ & Skin, joint, bone & $\begin{array}{l}\text { Bone scan-abnormal uptake in left parietal } \\
\text { bone, left proximal humeral epiphysis, right } \\
\text { 4th/5th/9th ribs, left ulna, right iliac, left } \\
\text { distal femoral epiphysis, left first } \\
\text { metatarsophalangeal joint. left L2 pedicle }\end{array}$ & 9,700 & Skin & Skin & 79 & 6.9 \\
\hline
\end{tabular}


blastomycosis at Children's Hospital of Wisconsin between 2000 and 2010 were reviewed retrospectively. Items analyzed included patient demographics, clinical findings, radiographic and laboratory data, treatment, and clinical sequelae (Table 1).

Seven of 31 (22.6\%) children diagnosed with $B$. dermatitidis infection had bone and/or joint involvement. Their ages ranged from 6 to 17 years and all were male. Six $(85.7 \%)$ of the 7 patients were urban dwellers from either metropolitan Milwaukee or Northern Chicago with no known exposure to a rural setting. Six children presented with either bone pain $(n=1)$ and/or arthralgia $(n=5)$. Although 3 of the children reported subjective fevers on history, none of the patients had documented fever at the time of presentation. One patient had asymptomatic bone involvement discovered on imaging. On examination, 5 (71\%) had signs of arthritis including joint swelling, erythema, and warmth ( 3 monoarticular, 1 with 2 joints affected, and 1 with 3 joints affected). All 7 patients had evidence suggestive of osteomyelitis on imaging studies (Figure 1) and in 5 cases, osteomyelitis was histologically confirmed. Of the joints affected, the majority were large joints including elbow, wrist, knee, and hip. Four of 7 had cutaneous lesions and 3 of 7 had pneumonia. Peripheral leukocyte count had a median value of $9.7 \times 10^{3} / \mu 1$ (range $\left.4.4-15.4 \times 10^{3} / \mu 1\right)$. Five patients had blood cultures prior to initiation of therapy; all blood cultures were negative. All 7 patients were immunocompetent and there were no preexisting degenerative lesions at the bone infected sites. Diagnosis of $B$. dermatitidis was by skin biopsy in 2 patients and bone biopsy in 4 patients by the presence of thick-walled, broad-based budding yeast identified through Gomori methenamine silver stain. Granulomatous inflammation was found on all 6 of the biopsy specimens. Bone cultures confirming $B$. dermatitidis were found in 3 patients and skin culture confirming $B$. dermatitidis was found in 2 patients. In Patient 2, diagnosis of B. dermatitidis was by bone culture alone. Three patients received intravenous (IV) liposomal amphotericin B $5 \mathrm{mg} / \mathrm{kg} /$ day for 2 months followed by oral itraconazole for 10 months. Patient 1 started IV liposomal amphotericin B $5 \mathrm{mg} / \mathrm{kg} /$ day but was switched to IV amphotericin B lipid complex 5 $\mathrm{mg} / \mathrm{kg} /$ day because of adverse reaction. This patient completed a 2-month course of IV amphotericin B lipid complex followed by 10 months of oral itraconazole. As a result of renal toxicity, Patient 2 received IV liposomal amphotericin B $3 \mathrm{mg} / \mathrm{kg} /$ day on 3 days per week to complete a 2-month course followed by 10 months of oral itraconazole. Patient 3 received 2 weeks of IV liposomal amphotericin B $5 \mathrm{mg} / \mathrm{kg} /$ day followed by itraconazole $300 \mathrm{mg}$ daily for 12 months. Patient 5 received only oral therapy with itraconazole. No patient had recurrence of infection after treatment.

To our knowledge, all patients in this case series were immunocompetent. However, immunosuppressed patients infected with blastomycosis appear more likely than healthy hosts to develop severe pulmonary infection and disseminated blastomycosis with a high rate of associated mortality ${ }^{11}$. Cases have been reported in adult patients with AIDS, in solid-organ transplant recipients, in stem cell transplant recipients, in patients with hematologic malignancies, and in patients receiving corticosteroids ${ }^{11}$. We are unaware of any cases reported in the literature of blastomycosis in immunocompromised children.

The Infectious Diseases Society of America (IDSA) guidelines for the treatment of pulmonary or disseminated blastomycosis in immunocompetent adults include amphotericin B, given as a lipid formulation, 3-5 $\mathrm{mg} / \mathrm{kg}$ per day, or amphotericin B deoxycholate $0.7-1 \mathrm{mg} / \mathrm{kg}$ per day, for 1-2 weeks, followed by step-down itraconazole, $200 \mathrm{mg} 3$ times per day for 3 days and then twice per day, to complete a total of 12 months of therapy ${ }^{11}$. Treatment with itraconazole alone for 6-12 months can be considered in cases of mild or localized disease ${ }^{11}$. Treatment recommendations are similar in immunocompromised patients and children, although there are limited data. However, IDSA guidelines recommend consideration of lifelong suppressive therapy, with oral itraconazole $200 \mathrm{mg}$ per

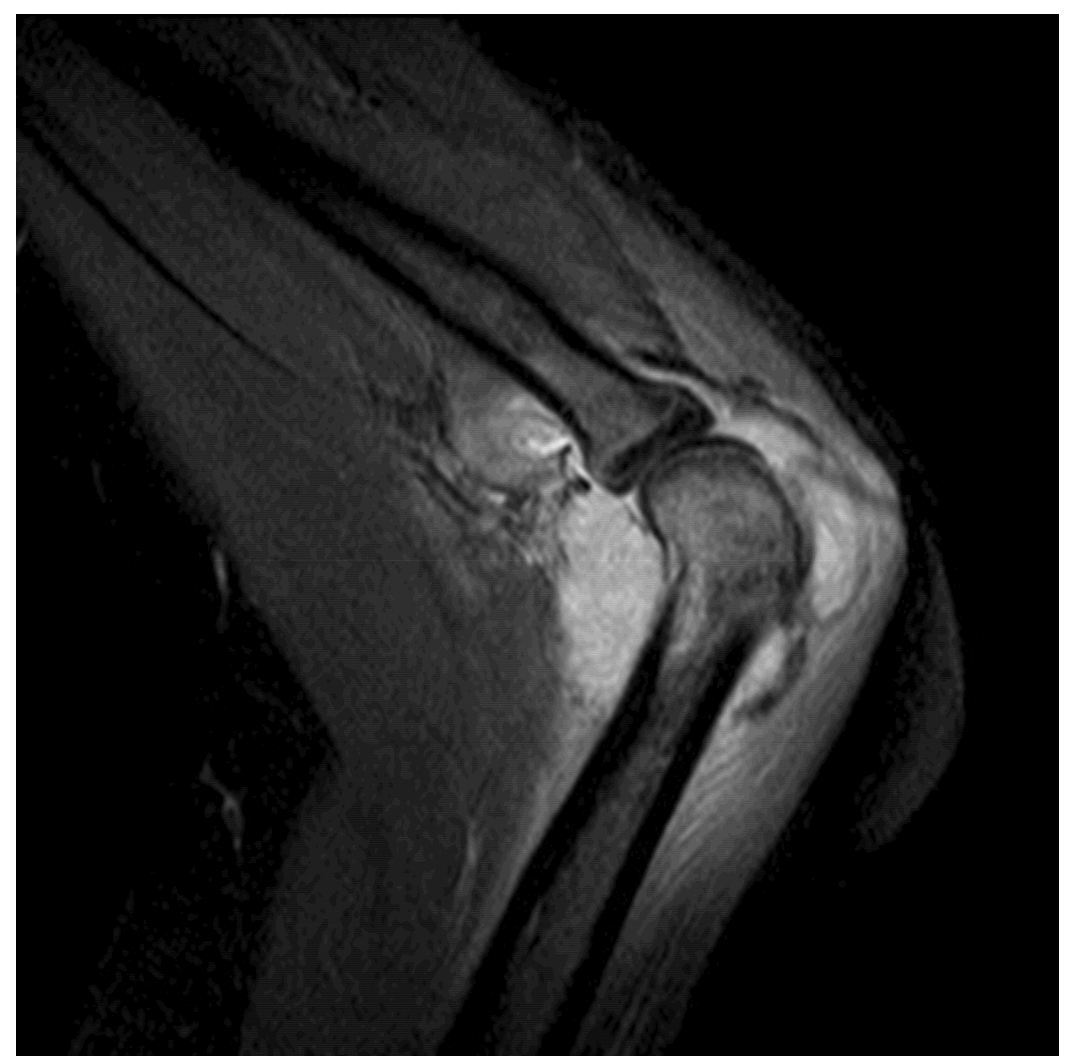

Figure 1. Patient had evidence suggestive of osteomyelitis. 
day, if immunosuppression cannot be reversed and in patients who experience relapse despite appropriate therapy ${ }^{11}$.

All our patients received a 12-month course of therapy with complete resolution of symptoms and no recurrence; however, only Patient 3 received a course consistent with the IDSA recommendations. The majority of patients in this case series received a much longer course of either liposomal amphotericin B or amphotericin B lipid complex. On review of the literature, the majority of disseminated cases in children (including bone/joint involvement) received parenteral liposomal amphotericin B at smaller doses of 10 to $35 \mathrm{mg} / \mathrm{kg}$ total followed by a $2-6$ month course of itraconazole or ketoconazole. However, there have been reports of cases of disease recurrence in children with pulmonary blastomycosis who received $<30 \mathrm{mg} / \mathrm{kg}$ parenteral antifungal therapy ${ }^{9}$. Based on literature review and our own case series, the IDSA guidelines regarding dose and length of parenteral antifungal therapy in pulmonary or disseminated blastomycosis are appropriate. However, it is reasonable to consider shortening the subsequent course of itraconazole to 6 months. Patients with only monoarticular joint involvement can be considered as having only mild to moderate disease and an oral course of itraconazole for 6-12 months can be considered appropriate therapy. None of our patients or patients reviewed in the literature were immunocompromised; thus we cannot comment on the IDSA guidelines regarding treatment of blastomycosis in this population.

Blastomycosis usually manifests as a respiratory illness in children but can present as an isolated osteomyelitis or arthritis. This disease should be considered in the differential diagnosis of septic arthritis or osteomyelitis, especially in endemic areas. Our cases suggest that children infected with $B$. dermatitidis should be evaluated for bone and joint involvement. $B$. dermatitidis infections of the bone and joint respond well to appropriate antifungal therapy, but can result in poor outcomes if not promptly and adequately treated, including joint destruction and even death ${ }^{7,10,11,12}$. Based on our findings, $B$. dermatitidis appears to be increasing in incidence in the urban setting and should be considered in the differential of septic arthritis or osteomyelitis for both rural and urban locations. To our knowledge, this is the second report of polyarticular joint involvement in children.

RACHEL R. JOHNSON, MD, Medical Education Office, Suite 430, Children's Corporate Center, Medical College of Wisconsin, 999 North 92nd Street, Milwaukee, Wisconsin 53226, USA; SHEETAL S. VORA, MD, Pediatric Rheumatology, Levine Children's Hospital, Carolinas Medical Center, Charlotte, North Carolina, USA.

Address correspondence to Dr. Johnson; E-mail: rajohnson@mcw.edu

\section{ACKNOWLEDGMENT}

We thank Dr. Carla Quijano for her contribution to this article.

\section{REFERENCES}

1. Furcolow ML, Balows A, Menges RW, Pickar D, McClellan JT, Saliba A. Blastomycosis. An important medical problem in the Central United States. JAMA 1966;198:529-32.

2. Body BA. Cutaneous manifestation of systemic mycoses. Dermatol Clin 1996;14:125-35.

3. Schwarz J, Baum GL. Blastomycosis. Am J Clin Pathol 1951;21:999-1029.

4. Hughes WT, Franco S, O MH. Systemic blastomycosis in childhood. Case report and review. Clin Pediatr 1969;8:597-601.

5. Abril A, Campbell MD, Cotton R Jr, Stecklebery JM, El-Azhary RA, O'Duffy JD. Polyarticular blastomycotic arthritis. J Rheumatol 1998;26:1019-21

6. Baumgardner DJ, Buggy BP, Mattson BJ, Burdick JS, Ludwig D. Epidemiology of blastomycosis in a region of high endemicity in north-central Wisconsin. Clin Infect Dis 1992;15:629-35.

7. Varkey B. Blastomycosis in children. Semin Respir Infect 1997;12:235-42.

8. MacDonald PB, Black GB, Mackenzie R. Orthopaedic manifestations of blastomycosis. J Bone Joint Surg Am 1990;72:860-4.

9. Schutze GE, Hickerson SL, Fortin EM, Schellhase DE, Darville T, Gubbins PO, et al. Blastomycosis in children. Clin Infect Dis 1996;22:496-502.

10. Head AJ, Myers LK, Thompson JD, Buckingham SC, Skinner RB. Disseminated blastomycosis presenting as oligoarticular septic arthritis in a 12-year-old girl. Arthritis Rheum 2005;53:138-41.

11. Chapman SW, Dismukes WE, Proia LA, Bradsher RW, Pappas PG, Thelkeld MG, et al. Clinical practice guidelines for the management of blastomycosis: 2008 update by the Infectious Diseases Society of America. Clin Infect Dis 2008;46:1801-12.

12. Robert ME, Kauffman CA. Blastomycosis presenting as polyarticular septic arthritis. J Rheumatol 1988;15:1438-42.

J Rheumatol 2013;40:9; doi:10.3899/jrheum.121115 